\title{
Soil Management Technologies and Mycotoxin Contamination of Wheat and Barley Grain
}

\author{
P. MATUŠInSKY ${ }^{1 *}$, M. VÁŇOVÁ ${ }^{1}$, L. TVARU゚ŽEK ${ }^{1}$, I. PolišEnSKÁ ${ }^{1}$, M. JANEČEK ${ }^{2}$ and V. SMUTNÝ ${ }^{3}$ \\ ${ }^{1}$ Agrotest Fyto, Ltd, Havlíčkova 2787/121, 76701 Kroměříž, Czech Republic \\ ${ }^{2}$ Crop Research Institute, Drnovská 507/73, 16106 Prague 6 - Ruzyně, Czech Republic \\ ${ }^{3}$ Mendel University in Brno, Zemědělská 1, 61300 Brno, Czech Republic
}

(Received 5 August 2015; Accepted 27 October 2015;

Communicated by X.F. Zhang)

\begin{abstract}
Fusarium head blight caused by a complex of Fusarium species is widespread across the world and ranks among the most serious diseases in cereals. Long-term field experiments were set up to evaluate the effects of preceding crop and soil management methods on Fusarium mycotoxin (DON, deoxynivalenol) contamination of winter wheat and spring barley grain. Winter wheat and spring barley were cultivated at two locations in the Czech Republic (A: Ivanovice na Hané during 2002-2014, and B: Žabčice during 2007-2014) with preceding crops (A) alfalfa, maize, and pea; and (B) alfalfa (only for wheat), sugar beet (only for barley), and maize. Different soil management methods also were used: (A) $22 \mathrm{~cm}$ tillage, $15 \mathrm{~cm}$ tillage, $10 \mathrm{~cm}$ chisel, and direct drilling; and (B) $22 \mathrm{~cm}$ tillage, $10 \mathrm{~cm}$ chisel, and direct drilling. Mycotoxin content in harvested grain was analysed using ELISA. At both locations in the experiments with both wheat and barley, year had a significant effect on mycotoxin content in grain. Preceding crop was another significant factor in wheat experiments at both locations, with DON content in grain higher with maize as the preceding crop than in the cases of other preceding crops. Soil management method had a significant effect only on mycotoxin content in wheat grain grown at Žabčice, and the highest DON content was determined in the chisel variant, in which case a large amount of harvest residue remained on the soil surface or was only partially incorporated.
\end{abstract}

Keywords: cereals, Fusarium head blight, Fusarium culmorum, Fusarium graminearum

\section{Introduction}

Fusarium head blight (FHB) caused by a complex of Fusarium species is widespread across the world and ranks among the most serious diseases in cereals. FHB in wheat and barley is characterized by early death of ears or their whitening. The disease is important especially in more humid regions. Once ears are infected, significant yield losses caused by spikelet sterility and insufficiently developed caryopses as well as grain contamination with mycotoxins can be expected (Champeil et al. 2004a). A large number of species from the genus Fusarium are involved in FHB's development, but the most frequent and most significant of these are F. graminearum, F. culmorum, F. avenaceum, and F. poae (Bai

\footnotetext{
*Corresponding author; E-mail: matusinsky@vukrom.cz; Phone: +420 573317113
} 
and Shaner 1994; Nicholson et al. 2003; Landschoot et al. 2012). The species F. graminearum and F. culmorum are predominant within the Czech Republic (Nedělník et al. 2007; Váňová et al. 2008). The most recent studies across Europe have indicated a rising proportion of $F$. poae (Audenaert et al. 2009; Lindblad et al. 2013). FHB's damage consists in yield reduction but especially in the ability of its numerous pathogens to produce mycotoxins. Fusarium mycotoxins can induce serious health problems in both humans and farm animals. As a consequence, different forms of chronic or acute mycotoxicosis appear (indigestion, fertility defects, etc.). The most frequent Fusarium mycotoxins are trichothecenes, particularly deoxynivalenol and nivalenol, and zearalenones. These harmful mycotoxins in grain are produced especially when the grain is infected by F. graminearum or F. culmorum. There exists, however, a series of other toxins caused by other Fusarium species, such as T2 and HT2 toxins produced by F. langsethiae and F. sporotrichioides (Matušinsky et al. 2013).

A large number of fungicides against FHB in cereals are registered in the Czech Republic. Also, registered are products for biological protection. Plant protection against FHB, just as for other diseases, is not based solely on pesticide application but includes cultivar selection and a complex of preventive and agronomic strategies that can to a large extent prevent strong disease infection (Pereyra and Dill-Macky 2008; Chandelier et al. 2011; Váňová et al. 2011; Vogelgsang et al. 2011; Landschoot et al. 2012, 2013). The purpose of comprehensive plant protection is to take into consideration all available methods that suppress the development of harmful organisms. Many indirect protection methods may be more effective and lower in cost than is pesticide application. This is true especially in the cases of diseases for which the efficacy of pesticide treatment is not generally consistent and complete. This group includes FHB, where some Fusarium species occur without apparent symptoms and the grain is nevertheless contaminated with mycotoxins. Although some recent papers have dealt with the effect of agronomic practices on FHB (Chandelier et al. 2011; Vogelgsang et al. 2011; Blandino et al. 2012; Landschoot et al. 2013), there remains a lack of knowledge about the effects of many factors and the interactions among them.

The objective of the present study was to evaluate the hypothesis that soil management method following preceding crops which host fusariosis, in particular maize, has a significant effect on FHB intensity or DON content in wheat grain. In contrast, no significant effect is predicted for preceding crops which do not host fusariosis, as no inoculum source or suitable substrate for pathogen multiplication remains following non-host crops. The hypothesis was tested at two locations in long-term field trials.

\section{Material and Methods}

\section{Field trials}

We performed long-term field trials at two locations in the Czech Republic. The first took place at Ivanovice na Hané (wheat during 2002-2014 and barley during 2012-2014) and the second at Žabčice (during 2007-2014 for both wheat and barley). Trials were arranged in a split-plot design with different variants of preceding crops as the main plots 
and different variants of soil management as subplots in four replicates. Due to cost constraints, only one mixed sample from all four replications was analysed for mycotoxins at Ivanovice na Hané. Samples from all four replications at Žabčice were analyzed for mycotoxins.

\section{Experiment A, 2002-2014, Ivanovice na Hané}

The Ivanovice experimental station is located at $49^{\circ} 19^{\prime} \mathrm{N} 17^{\circ} 05^{\prime} \mathrm{E}$ in the cadastral area of Ivanovice na Hané. The experimental location lies within a beet-growing area at 225 $\mathrm{m}$ a.s.l. The soil is fertile and naturally supplied with major nutrients. The soil type is loamy degraded chernozem. The soil-forming substrate is loess, with primarily alluvial and diluvial loamy soils on loess subsoils. The topsoil is dark brown and humic and reaches average depths of ca $40 \mathrm{~cm}$. According to the data from the local meteorological station, the 20 -year average temperature is $9.17^{\circ} \mathrm{C}$ and annual precipitation is $548.1 \mathrm{~mm}$.

The trial was organized and conducted as a 6 -field crop rotation with 2 years of alfalfa (spring barley, alfalfa - 1st year, alfalfa - 2nd year, winter wheat, maize for silage, sugar beet) using various soil management methods (22 and $15 \mathrm{~cm}$ tillage, no tillage, and $10 \mathrm{~cm}$ chisel). The Sulamit variety of winter wheat was grown and the Bojos variety of barley, both sown at agronomically proper times. No fungicides were applied to winter wheat or barley. $\mathrm{P}$ and $\mathrm{K}$ fertilizers were applied in autumn: superphosphate at $90 \mathrm{~kg} \mathrm{P}_{2} \mathrm{O}_{5}$ for wheat and $70 \mathrm{~kg} \mathrm{P}_{2} \mathrm{O}_{5}$ for barley and potassium salt at $50 \mathrm{~K}_{2} \mathrm{O}$ for wheat and $35 \mathrm{~kg} \mathrm{~K} \mathrm{~K}_{2} \mathrm{O}$ for barley. Total $\mathrm{N}$ application for wheat was $120 \mathrm{~kg}$, with $60 \mathrm{~kg}$ in autumn in the form of ammonium sulphate. $\mathrm{N}$ was applied to barley only in spring at a rate of $40 \mathrm{~kg} \mathrm{ha}^{-1}$. In 2003, the trial at Ivanovice na Hané was destroyed by frost, and so data for that year were not included into the overall evaluation.

\section{Experiment B, 2007-2014, Žabčice}

The Žabčice location lies within a maize-growing area at $49^{\circ} 31^{\prime} \mathrm{N} 16^{\circ} 48^{\prime} \mathrm{E}$ with average annual temperature of $9.2^{\circ} \mathrm{C}$ and annual precipitation of $480 \mathrm{~mm}$. These indicators place the location among the driest areas in the Czech Republic. Drought occurrence is to a certain extent compensated by the fine-grained fluvisol soil (the proportion of fine clay particles is greater than 50\%) and a relatively high level of underground water, which is influenced by the fluctuating level of the Svratka River, which runs near the experimental location.

The trial was organized and conducted as a 7-field crop rotation with 2 years of alfalfa (alfalfa - 1st year, alfalfa - 2nd year, winter wheat, maize for silage, winter wheat, sugar beet, spring barley). The Sultan variety of winter wheat was grown and the Bojos variety of barley, both sown at agronomically proper times. The trial used the following soil management methods: $22 \mathrm{~cm}$ tillage, $10 \mathrm{~cm}$ chisel, and direct seeding (direct seeding combined with no prior soil preparation). No fungicides were applied to winter wheat or barley. $\mathrm{P}$ and $\mathrm{K}$ mineral fertilizers were applied following crop harvests (except for the field with the first year of alfalfa) using stock granulated superphosphate $\left(19 \% \mathrm{P}_{2} \mathrm{O}_{5}\right)$ at 
$90 \mathrm{~kg} \mathrm{P}_{2} \mathrm{O}_{5}$ and potassium salt $\left(60 \% \mathrm{~K}_{2} \mathrm{O}\right)$ at $130 \mathrm{~kg} \mathrm{~K} \mathrm{~K}_{2} \mathrm{O}$. Total $\mathrm{N}$ application rate was $150 \mathrm{~kg} \mathrm{~N} \mathrm{ha}{ }^{-1}$. Nitrogen was applied at $60 \mathrm{~kg}$ prior to sowing using ammonium nitrate with limestone. Due to organizational changes, DON analysis was not conducted during 2009 and 2010, and so these years were not included into the results.

\section{Mycotoxin analysis}

Mycotoxins content was analyzed by ELISA using R-Biopharm AG kits (Darmstadt, Germany). A combination of RIDASCREEN ${ }^{\circledR}$ DON and RIDACREEN ${ }^{\circledR}$ FAST DON kits was used to determine DON. The limit of quantification for DON was $20 \mu \mathrm{g} \mathrm{kg}^{-1}$. Analyses were carried out according to the manufacturer's guidelines. The method for determining DON was accredited in the laboratory by the Czech Accreditation Institute according to the Czech national standard CSN EN ISO/IEC 17025:2005. The quality of mycotoxin results is regularly verified in FAPAS ${ }^{\circledR}$ ring tests. Statistica 12.0 software was used for statistical analyses. Analyses of variance were performed based on differences in DON content. All data are presented non-transformed but, before ANOVA, they were subjected to $\log 10$ transformation.

\section{Results}

Ivanovice location (A), wheat

The 12-year trial monitored the effects of preceding crop and various soil management methods on DON content in harvested wheat grain. Higher level of mycotoxin was present after preceding crop maize (Table 1). Year had a substantial effect on the level of wheat contamination. Significantly higher mycotoxin levels were determined in 2005 and 2007 in comparison to other years (Table 1). Soil management method did not significantly affect mycotoxin content. Analysis of only the data acquired from maize as preceding crop, where an effect is expected from additional movement of harvest residues (i.e. a source of inoculum for the level of grain contamination), revealed no significant differences among individual tillage variants. Despite the lack of significant differences, however, the lowest mycotoxin content $\left(654.55 \mu \mathrm{g} \mathrm{kg}^{-1}\right)$ was measured after $22 \mathrm{~cm}$ tillage.

\section{Ivanovice location (A), barley}

The trial with barley took place over 3 years (2012-2014) with the same variant setup as for wheat. Year was a factor with a significant effect on the contamination level of barley grain. A significantly higher contamination level was determined in 2012 in comparison to the other monitored years (Table 2). Neither preceding crop nor soil management method had a significant effect on DON content. 
Table 1. Analysis of variance and Tukey's test for DON content in winter wheat grain grown at Ivanovice na Hané during 2002-2014 after different preceding crops

\begin{tabular}{|c|c|c|c|}
\hline Year & DON $\left(\mu \mathrm{g} \mathrm{kg}^{-1}\right)^{*}$ & Preceding crop & DON $\left(\mu \mathrm{kg}^{-1}\right)^{*}$ \\
\hline 2014 & $13.612^{\mathrm{a}}$ & Alfalfa & $194.8582^{\mathrm{a}}$ \\
\hline 2011 & $13.733^{\mathrm{a}}$ & Pea & $244.5332^{\mathrm{a}}$ \\
\hline 2002 & $34.417^{\mathrm{a}}$ & Maize & \\
\hline 2010 & $63.667^{\mathrm{a}}$ & & \\
\hline 2012 & $76.490^{\mathrm{ab}}$ & & \\
\hline 2013 & $78.053^{\mathrm{ab}}$ & & \\
\hline 2008 & $219.417^{\mathrm{bc}}$ & & \\
\hline 2009 & $300.829^{\mathrm{cd}}$ & & \\
\hline 2006 & $379.908^{\mathrm{cde}}$ & & \\
\hline 2004 & $788.742^{\mathrm{def}}$ & & \\
\hline 2007 & $1373.267^{\mathrm{ef}}$ & & \\
\hline 2005 & $1724.919^{\mathrm{f}}$ & & \\
\hline
\end{tabular}

*Variables with differing letters for Tukey's test $(P<0.05)$ differ significantly from one another.

Table 2. Analysis of variance and Tukey's test for DON content in spring barley grain grown at Ivanovice na Hané during 2012-2014

\begin{tabular}{|c|c|}
\hline Year & DON $\left(\mu \mathrm{g} \mathrm{kg}^{-1}\right)^{*}$ \\
\hline 2014 & $8.2424^{\mathrm{a}}$ \\
\hline 2013 & $18.5846^{\mathrm{a}}$ \\
\hline 2012 & $146.1561^{\mathrm{b}}$ \\
\hline
\end{tabular}

*Variables with differing letters for Tukey's test $(P<0.05)$ differ significantly from one another.

\section{Žabčice location (B), wheat}

The 6-year trial monitored the effects of preceding crop and various soil management methods on DON content in harvested wheat grain (Table 3). Year had a substantial effect on the level of wheat grain contamination. A significantly higher mycotoxin level was determined in 2013 compared to other years, while the contamination level was lowest in 2014 (Table 3). Preceding crop also significantly affected grain contamination level. Significantly greater contamination $\left(928.48 \mu \mathrm{g}\right.$ DON kg$\left.{ }^{-1}\right)$ was determined following maize (Table 3). Soil management method also significantly affected mycotoxin content (Table 3). Evaluating only the data acquired from maize as preceding crop revealed a similar situation. When maize residues (straw and cob residues) as sources of inoculum were incorporated into the soil, significantly lower DON content was measured $(416 \mu \mathrm{g}$ $\left.\mathrm{kg}^{-1}\right)$ in comparison to chisel ploughing to $10 \mathrm{~cm}\left(1,386.58 \mu \mathrm{g} \mathrm{kg}^{-1}\right)$, where residues were only partially incorporated into the soil (Table 4). 


\section{Žabčice location (B), barley}

During 2007-2014, two independent trials with spring barley were established at Žabčice. The first had maize as preceding crop with two soil management methods (tillage, chisel) and the second had sugar beet as preceding crop with three different soil management

Table 3. Analysis of variance and Tukey's test for DON content in winter wheat grain grown at Žabčice during 2007-2014 with experimental factors

\begin{tabular}{|c|c|c|c|}
\hline Year & DON $\left(\mu \mathrm{g} \mathrm{kg}^{-1}\right)^{*}$ & Soil management & DON $\left(\mu \mathrm{kg}^{-1}\right)^{*}$ \\
\hline 2014 & $68.733^{\mathrm{a}}$ & $22 \mathrm{~cm}$ tillage & $279.1116^{\mathrm{a}}$ \\
\hline 2012 & $112.831^{\mathrm{b}}$ & Direct drilling & $583.8881^{\mathrm{ab}}$ \\
\hline 2008 & $629.500^{\mathrm{c}}$ & $10 \mathrm{~cm}$ chisel & $789.8345^{\mathrm{b}}$ \\
\hline 2011 & $678.333^{\mathrm{c}}$ & Preceding crop & ${\text { DON }\left(\mu \mathrm{g} \mathrm{kg}^{-1}\right)^{*}}^{\mathrm{c}}$ \\
\hline 2007 & $746.000^{\mathrm{cd}}$ & Alfalfa & $173.4103^{\mathrm{a}}$ \\
\hline 2013 & $1070.271^{\mathrm{e}}$ & Maize & $928.4792^{\mathrm{b}}$ \\
\hline
\end{tabular}

*Variables with differing letters for Tukey's test $(P<0.05)$ differ significantly from one another.

Table 4. Analysis of variance and Tukey's test for DON content in winter wheat grain grown only following maize as preceding crop at Žabčice during 2007-2014 with different soil management

\begin{tabular}{|c|c|c|c|}
\hline Year & DON $\left(\mu \mathrm{g} \mathrm{kg}^{-1}\right)^{*}$ & Soil management & DON $\left(\mu \mathrm{gg}^{-1}\right)^{*}$ \\
\hline 2012 & $90.191^{\mathrm{a}}$ & $22 \mathrm{~cm}$ tillage & $416.091^{\mathrm{a}}$ \\
\hline 2014 & $118.178^{\mathrm{a}}$ & Direct drilling & $982.769^{\mathrm{ab}}$ \\
\hline 2007 & $1151.333^{\mathrm{b}}$ & $10 \mathrm{~cm}$ chisel & \\
\hline 2008 & $1191.667^{\mathrm{b}}$ & & \\
\hline 2011 & $1193.000^{\mathrm{b}}$ & & \\
\hline 2013 & $1826.506^{\mathrm{bc}}$ & & \\
\hline
\end{tabular}

*Variables with differing letters for Tukey's test $(P<0.05)$ differ significantly from one another.

Table 5. Analysis of variance and Tukey's test for DON content in spring barley grain grown only following sugar beet as preceding crop at Žabčice during 2007-2014

\begin{tabular}{|c|c|}
\hline Year & DON $\left(\mu \mathrm{g} \mathrm{kg}^{-1}\right)^{*}$ \\
\hline 2010 & $22.6667^{\mathrm{a}}$ \\
\hline 2011 & $54.3333^{\mathrm{a}}$ \\
\hline 2014 & $71.0000^{\mathrm{a}}$ \\
\hline 2013 & $104.6667^{\mathrm{ab}}$ \\
\hline 2008 & $106.0000^{\mathrm{ab}}$ \\
\hline 2009 & $147.3333^{\mathrm{b}}$ \\
\hline 2007 & $261.0000^{\mathrm{c}}$ \\
\hline 2012 & $399.5833^{\mathrm{d}}$ \\
\hline
\end{tabular}

*Variables with differing letters for Tukey's test differ significantly from one another. 
methods (tillage, chisel, direct drilling). In the first experiment with maize as preceding crop, year had a substantial effect on the level of barley grain contamination. A significantly higher mycotoxin level was determined in 2009 in comparison to other years. Soil management method did not have a significant effect, although a higher level of DON contamination was recorded for chisel. Similarly, year was also a significant factor in the second experiment with sugar beet as preceding crop (Table 5). Soil management method also did not have a significant effect on contamination, although the mycotoxin level in barley grain was slightly higher following chisel.

\section{Discussion}

Fungicide application is usually the only measure taken to decrease FHB infection and mycotoxin accumulation. To protect cereals from FHB, however, it is necessary to integrate multiple strategies, such as managing previous crop residues (Dill-Macky and Jones 2000), choosing the cropping system (Dill-Macky and Jones 2000; Champeil et al. 2004a; Lori et al. 2009), and selecting the proper cultivar (Blandino et al. 2012). Our long-term field trials monitored at two locations the effects of preceding crop and soil management method on contamination of harvested wheat and barley grains by the mycotoxin DON. DON content frequently does not correlate with visible ear infection, and so our evaluation focused on measuring the level of mycotoxin contamination as this indicator has the greatest practical importance.

In current study had year substantial effect on the level of wheat grain contamination by DON in Ivanovice location. Previous research has shown that FHB incidence and mycotoxin content vary strongly among years. Weather conditions are the most important factors determining disease pressure. Schaafsma and Hooker (2007) and Klem et al. (2007) had concluded that there can be observed a strong effect of weather conditions during anthesis on FHB incidence and DON content. Furthermore, weather conditions contribute to disease pressure also during the vegetative growth stage (Kriss et al. 2010; Landschoot et al. 2012). Preceding crop also had a significant effect on the level of grain contamination in this study at Ivanovice location. Significantly higher contamination was determined following maize. As it has been determined in previous studies, the intensity and frequency of wheat and maize rotation play an important part in FHB epidemiology (Landschoot et al. 2013). In our study, soil management method did not significantly affect mycotoxin content in wheat grain (location Ivanovice). Favourable weather conditions are likely to be more important than are tillage practice and fertilizer treatments (Lori et al. 2009). The effect of tillage practices has been studied previously. Lori et al. (2009) reported DON content 1.4 times higher in plots with minimal tillage, whereas Blandino et al. (2012) reported that the mean DON content in plots with no tillage was 4.3 times higher than it was in fields that were ploughed before sowing. The observed relationship between increased FHB and maize residue agrees with earlier studies in which FHB epidemics were associated with wheat-maize rotations. Previous crop residues and tillage practices affected the incidence and severity of FHB differently. Wheat grown after soybeans had reduced FHB incidence and severity compared to wheat grown after 
wheat or maize, regardless of tillage practice. FHB levels have been observed to be higher when wheat was grown after maize than when it followed wheat (Dill-Macky and Jones 2000).

Neither preceding crop nor soil management method had a significant effect on DON content in location Ivanovice with barley. Most studies on FHB have documented a significant increase in infection in the case of minimum tillage or no-till treatments (DillMacky and Jones 2000; Champeil et al. 2004b; Koch et al. 2006; Maiorano et al. 2008), but in certain experiments, similarly to our results, no significant effects on FHB or DON have been observed (Schaafsma et al. 2001).

Soil management method significantly affected mycotoxin content in wheat grain in Žabčice location. Moreover, evaluating only the data acquired from maize as preceding crop revealed similar situation. When maize residues as sources of inoculum were incorporated into the soil, significantly lower DON content was measured in comparison to chisel ploughing, where residues were only partially incorporated into the soil. When maize residues remain on the soil surface, they act as a source of inoculum but they also dry out, which state is less conducive to the growth of fungi as opposed to when stem and cobs parts are partially turned into the soil. In the latter case, these residues draw moisture from the ground and are therefore ideal sources of inoculum, as experimentally confirmed in our study. In previous work by Landschoot et al. (2013), experimental results showed that the harvest method of maize (for grain or silage) had only a minor effect on the FHB incidence and DON content of the wheat crop during the subsequent cropping season. Tillage method and wheat variety resistance were more important, and both factors had a significant effect on FHB incidence and DON content. Such crop residues as maize stalks are reservoirs upon which pathogens survive saprophytically. Chopping and grinding maize residues to reduce the size of stalk pieces may also favour more rapid disintegration of infected tissues (Landschoot et al. 2013). Furthermore, the effect of tillage practices varies to a great extent with climatic conditions (Blandino et al. 2010; Leplat et al. 2013).

In conclusion cereals planted following maize or another host crop may have an increased chance of FHB infection in environmentally conducive years and locations at risk. Rotating cereals with non-host crops has been shown to reduce FHB infection and mycotoxin contamination. When the preceding crop is a host crop, subsequent soil management method is important. Incorporating harvest residues which are sources of inoculum into the soil decreases the risk of grain being contaminated by mycotoxin. In contrast, if such harvest residues as maize stalks and cob residues are ploughed down only shallowly and partially protrude above the soil surface while obtaining sufficient moisture from the soil, ideal conditions are created for inoculum multiplication and the risk of grain being contaminated by mycotoxin increases. The results obtained in our experiments indicate that differences in the way crop residues are managed after the preceding crop is harvested may affect disease development and suggest that local sources of inoculum, such as maize residues, contribute directly to inoculum load and disease potential. Although from now into the near future protection against FHB will probably depend on 
applying fungicide and perhaps also selection of resistant varieties (host resistance), such implications of our findings as the importance of selecting suitable agronomic practices will contribute substantially to FHB's management.

\section{Acknowledgements}

This work was supported by National Agency for Agricultural Research projects nos QJ1210008, QI111B044, QJ1530373 and QJ1310091 as well as the institutional support of long-term conceptual development of research organization, projects nos RO0211 and RO0414.

\section{References}

Audenaert, K., Van Broeck, R., Bekaert, B., De Witte, F., Hermans, B., Messens, K., Höfte, M., Haesaert, G. 2009. Fusarium head blight (FHB) in Flanders: population diversity, inter-species associations and DON contamination in commercial winter wheat varieties. Eur. J. Plant Pathol. 125:445-458.

Bai, G., Shaner, G.E. 1994. Scab of wheat: prospects for control. Plant Disease 78:760-766.

Blandino, M., Haidukowski, M., Pascale, M., Plizzari, L., Scudellari, D., Reyneri, A. 2012. Integrated strategies for the control of Fusarium head blight and deoxynivalenol contamination in winter wheat. Field Crops Res. 133:139-149.

Blandino, M., Pilati, A., Reyneri A., Scudellari, D. 2010. Effect of maize crop residue density on Fusarium head blight and on deoxynivalenol contamination of common wheat grains. Cereal Res. Commun. 38:550-559.

Champeil, A., Doré, T., Fourbet, J.F. 2004a: Fusarium head blight: epidemiological origin of the effects of cultural practices on head blight attack and the production of mycotoxins by Fusarium in wheat grains. Plant Sci. 166:1389-1415.

Champeil, A., Fourbet, J.F., Doré, T., Rossignol, L. 2004b. Influence of cropping system on Fusarium head blight and mycotoxin levels in winter wheat. Crop Protection 23:531-537.

Chandelier, A., Nimal, C., André, F., Planchon, V., Oger, R. 2011. Fusarium species and DON contamination associated with head blight in winter wheat over a 7-year period (2003-2009) in Belgium. Eur. J. Plant Pathol. 130:403-414.

Dill-Macky, R., Jones, R.K. 2000. The effect of previous crop residues and tillage on Fusarium head blight of wheat. Plant Disease 84:71-76.

Klem, K., Váňová, M., Hajšlová, J., Lancová, K., Sehnalová, M. 2007. A neural network model for prediction of deoxynivalenol content in wheat grain based on weather data and preceding crop. Plant Soil Environ. 53:421-429.

Koch, H.J., Pringas, C., Maerlaender, B. 2006. Evaluation of environmental and management effects on Fusarium head blight infection and deoxynivalenol concentration in the grain of winter wheat. Eur. J. Agron. 24:357-366.

Kriss, A.B., Paul, P.A., Madden, L.V. 2010. Relationship between yearly fluctuations in Fusarium head blight intensity and environmental variables: a window-pane analysis. Phytopathol. 100:784-797.

Landschoot, S., Audenaert, K., Waegeman, W., De Baets, B., Haesaert, G. 2013. Influence of maize-wheat rotation systems on Fusarium head blight infection and deoxynivalenol content in wheat under low versus high disease pressure. Crop Protection 52:14-21.

Landschoot, S., Waegeman, W., Audenaert, K., Vandepitte, J., Baetens, J.M., De Baetes, B., Haesaert, G. 2012. An empirical analysis of explanatory variables affecting Fusarium head blight infection and deoxynivalenol content in wheat. J. Plant Pathol. 94:135-147.

Leplat, J., Friberg, H., Abib, M., Steinberg, C. 2013. Survival of Fusarium graminearum, the causal agent of Fusarium head blight. A review. Agronomy for Sustainable Development 33:97-111. 
Lindblad, M., Gidlund, A., Sulyok, M., Börjesson, T., Krska, R., Olsen, M., Fredlund, E. 2013. Deoxynivalenol and other selected Fusarium toxins in Swedish wheat - occurrence and correlation to specific Fusarium species. Int. J. Food Microbiol. 167:284-291.

Lori, G.A., Sisterna, M.N., Sarandón, S.J., Rizzo, I., Chidichimo, H. 2009. Fusarium head blight in wheat: impact of tillage and other agronomic practices under natural infection. Crop Prot. 28:495-502.

Maiorano, A., Blandino, M., Reyneri, A., Vanara, F. 2008. Effects of maize residues on the Fusarium spp. infection and deoxynivalenol (DON) contamination of wheat grain. Crop Prot. 27:182-188.

Matušinsky, P., Polišenská, I., Kadlíková, M., Tvarůžek, L., Spitzerová, D., Spitzer, T. 2013. Dynamics of T-2 toxin synthesis on barley ears. J. of Food, Agric. and Environ. 11:1114-1122.

Nedělník, J., Moravcová, H., Hajšlová, J., Lancová, K., Váňová, M., Salava, J. 2007. Fusarium spp. in wheat grain in the Czech Republic analysed by PCR method. Plant Protection Sci. 43:135-137.

Nicholson, P., Chandler, E., Draeger, R.C., Gosman, N.E., Simpson, D.R., Thomsett, M., Wilson, A.H. 2003. Molecular tools to study epidemiology and toxicology of Fusarium head blight of cereals. Eur. J. Plant Pathol. 109:691-703.

Pereyra, S.A., Dill-Macky, R. 2008. Colonization of the residues of diverse plant species by Gibberella zeae and their contribution to Fusarium head blight inoculum. Plant Disease 92:800-807.

Schaafsma, A.W., Hooker, D.C. 2007. Climatic models to predict occurrence of Fusarium toxins in wheat and maize. Int. J. Food Microbiol. 119:116-125.

Schaafsma, A.W., Tamburic-Illic, L., Miller, J.D., Hooker, D.C. 2001. Agronomic consideration for reducing deoxynivalenol in wheat grain. Can. J. Plant Pathol. 23:279-285.

Váňová, M., Klem, K., Míša, P., Matušinsky, P., Hajšlová, J., Lancová, K. 2008. The content of Fusarium mycotoxins, grain yield and quality of winter wheat cultivars under organic and conventional cropping systems. Plant Soil Environ. 54:395-402.

Váňová, M., Matušinsky, P., Javůrek, M., Vach, M. 2011. Effect of soil tillage practices on severity of selected diseases in winter wheat. Plant Soil Environ. 57:245-250.

Vogelgsang, S., Hecker, A., Musa, T., Dorn, B., Forrer, H.R. 2011. On-farm experiments over 5 years in a grain maize/winter wheat rotation: effect of maize residue treatments on Fusarium graminearum infection and deoxynivalenol contamination in wheat. Mycotoxin Res. 27:81-96. 